\title{
Grazing of phototrophic nanoplankton by microzooplankton in Narragansett Bay
}

\author{
Peter G. Verity \\ Graduate School of Oceanography, University of Rhode Island, Kingston, Rhode Island 02882, USA
}

\begin{abstract}
Daily photosynthetic nanoplankton $(<10 \mu \mathrm{m}$ and $<5 \mu \mathrm{m})$ growth rates and microzooplankton (10 to $202 \mu \mathrm{m}$ ) grazing rates were measured at weekly intervals for $1 \mathrm{yr}$ using size-fractionated natural populations incubated in situ in lower Narragansett Bay. Changes in $<10 \mu \mathrm{m}$ and $<5 \mu \mathrm{m}$ chlorophyll $a$ in the presence and absence of 10 to $202 \mu \mathrm{m}$ microzooplankton were used to calculate growth and grazing rates. $\mathrm{NH}_{4}, \mathrm{NO}_{3}, \mathrm{PO}_{4}$, and $\mathrm{Si}(\mathrm{OH})_{4}$ concentrations measured within the dialysis bags before and after in situ incubations indicated that nutrient availability was adequate to meet uptake requirements during these short experiments. Chl a growth rates ranged from 0 to 2.2 doublings $\mathrm{d}^{-1}(<10 \mu \mathrm{m})$ and 0 to 2.1 doublings $\mathrm{d}^{-1}(<5 \mu \mathrm{m})$, and increased with temperature. Microzooplankton

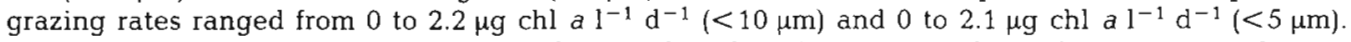
Grazing was linearly related to chl $a$ standing stock and production in each size fraction. Annual mean microzooplankton grazing represented $62 \%$ of $<10 \mu \mathrm{m}$ and $<5 \mu \mathrm{m}$ chl a production. Grazing impact was elevated when low temperatures limited nanoplankton production, suggesting that microzooplankton grazing contributed to seasonal variations in relative importance of different size fractions of phytoplankton in Narragansett Bay.
\end{abstract}

\section{INTRODUCTION}

Evaluating rates of in situ production by phytoplankton populations and transfer to higher trophic levels has long been a problem in plankton ecology. Methods of measuring productivity of natural phytoplankton communities include incorporation of radioactive labels (Steemann Nielsen 1952, Redalje 1983) and stable isotopes (Hama et al. 1983); measurement of changes in dissolved gases (Williams et al. 1983); calculation of water column net oxygen utilization rates (Jenkins 1982); and measurement of rates of synthesis of community biomass tracers such as ATP (Sheldon \& Sutcliffe 1978) and RNA (Karl et al. 1981). All of the methods which involve manipulating samples must minimize or avoid 'bottle effects' or containment problems which yield artificial results (Venrick et al. 1977, Eppley 1980). In situ incubation of natural phytoplankton populations in cage cultures after screening out grazers permits direct measurement of growth rates with a minimum of artifacts (Sakshaug \& Jensen 1978, Furnas 1982).

Methods of estimating the grazing impact of natural zooplankton populations include extrapolation from production rates and energy requirements (Durbin \& Durbin 1981); extrapolation from laboratory- or fielddetermined grazing rates of abundant species to population estimates (Heinbokel \& Beers 1979); and largevolume containment studies (Thompson et al. 1982). Small-volume incubations with macrozooplankton are generally not feasible due to low abundances, unless they are artificially concentrated (Roman \& Rublee 1981). However, microzooplankton have high specific feeding rates (Heinbokel 1978, Verity 1985) and are sufficiently numerous that small-volume incubations of natural populations are feasible. A major problem is that confinement in bottles results in the demise of ciliate populations (Venrick et al. 1977). Dialysis bags, on the other hand, have been used successfully to measure grazing and growth rates of natural microzooplankton communities (Landry \& Hassett 1982, Verity 1986).

Phytoplankton passing a $10 \mu \mathrm{m}$ mesh contributed $36 \%$ of annual chl $a$ standing stock in lower Narragansett Bay (Verity 1984), where microzooplankton are abundant year-round (Hargraves 1981, Verity 1984). Their small size, rapid metabolic rates, and preference for food particles that are inefficiently filtered by larger 
zooplankton (Nival \& Nival 1976) suggest that microzooplankton provide an important link in the transfer of photosynthetic nanoplankton production to higher trophic levels (Porter et al. 1979). In the present study, in situ incubations of $<10 \mu \mathrm{m}$ nanoplankton in the presence and absence of 10 to $202 \mu \mathrm{m}$ microzooplankton were conducted at weekly intervals for 1 yг to assess the grazing impact of microzooplankton on phototrophic nanoplankton populations in Narragansett Bay.

\section{METHODS}

Experiments were conducted at weekly intervals (n =52) between March 1982 and March 1983 at a station located in lower Narragansett Bay, Rhode Island $\left(41^{\circ} 30^{\prime} \mathrm{N}, 72^{\circ} 23^{\prime} \mathrm{W}\right)$ in $7 \mathrm{~m}$ of water. On the morning of an experiment, 4 lengths of large-diameter dialysis tubing (90 $\mathrm{mm}$ inflated diameter, $\mathrm{MW}$ cutoff 12,000 ) were autoclaved and rinsed in distilled water to remove glycerin. Each length of tubing was tied off at one end and transported to the experimental site, where a surface sample was collected using a 201 plastic bucket with a $202 \mu \mathrm{m}$ mesh across the mouth. Three of the 4 dialysis tubes were filled with $<202 \mu \mathrm{m}$ plankton by slowly raising them through the bucket. The $<10 \mu \mathrm{m}$ community was prepared by filling an acid-cleaned glass beaker with the $<202 \mu \mathrm{m}$ fraction and allowing a plexiglass cylinder with $10 \mu \mathrm{m}$ Nitex mesh on one end to sink by gravity. The $<10 \mu \mathrm{m}$ community inside the cylinder was siphoned into the fourth dialysis tube. The entire process took ca $20 \mathrm{~min}$, and the 4 bags were moored at $1 \mathrm{~m}$ for $24 \mathrm{~h}$. Experiments were generally initiated between 1000 and $1200 \mathrm{~h}$, as diel experiments indicated no significant differences in microzooplankton growth rates. Dialysis bags were used because preliminary experiments indicated persistent declines in ciliate populations incubated in Pyrex containers. Plexiglass cages with polycarbonate membranes were difficult to manipulate and quantitatively sample, due to changes in volume when the cages were withdrawn from water.

A portion of the $<202 \mu \mathrm{m}$ sample was returned to the laboratory for determination of initial chlorophyll a (chl a) and nutrient concentrations and microzooplankton abundance. $\mathrm{Chl}$ a was measured in triplicate in the $<153 \mu \mathrm{m},<10 \mu \mathrm{m}$, and $<5 \mu \mathrm{m}$ fractions by filtration onto Gelman A/E $0.45 \mu \mathrm{m}$ glass fiber filters. Comparison of Narragansett Bay plankton communities collected on Gelman $\mathrm{A} / \mathrm{E}$ and Whatman $\mathrm{GF} / \mathrm{F}$ filters revealed no significant differences in chl a over an annual cycle (Smayda unpubl.). One 1 of the $<202 \mu \mathrm{m}$ community was preserved with seawater-buffered formalin and concentrated by settling to a final volume of 5 to $10 \mathrm{ml}$ for determination of microzooplankton abundance. Another portion of the $<202 \mu \mathrm{m}$ fraction was filtered and frozen for subsequent determination of $\mathrm{NH}_{4}, \mathrm{NO}_{3}, \mathrm{PO}_{4}$, and $\mathrm{Si}(\mathrm{OH})_{4}$ concentrations. Comparison of $\mathrm{NH}_{4}$ concentration in fresh (phenol-hypochlorite method) and frozen (automated analysis) samples, ranging from undetectable to $36 \mu \mathrm{M}$, showed a mean loss of only $7 \%(\mathrm{n}=149)$ in frozen samples (Verity \& Sinayda unpubl.).

$\mathrm{Chl} a$ and microzooplankton abundance were measured after $24 \mathrm{~h}$ in each of the 3 dialysis bags containing $<202 \mu \mathrm{m}$ plankton, and $\mathrm{chl} a$ in the bag containing $<10 \mu \mathrm{m}$ plankton. Chl $a$ in the $<10 \mu \mathrm{m}$ and $<5 \mu \mathrm{m}$ fractions was determined after gently passing aliquots from the $<202 \mu \mathrm{m}$ and $<10 \mu \mathrm{m}$ bags through $10 \mu \mathrm{m}$ and $5 \mu \mathrm{m}$ meshes and filtering them in triplicate on glass fiber filters. Microzooplankton from the 3 dialysis bags containing $<202 \mu \mathrm{m}$ plankton were preserved and concentrated as previously described. Aliquots from each of the 4 bags were also filtered and frozen for subsequent measurement of nutrient concentrations.

Chl $a$ was extracted by grinding in $90 \%$ acetone and measured fluorometrically before and after acidification using the method of Holm-Hansen et al. (1965). $\mathrm{NH}_{4}, \mathrm{NO}_{3}, \mathrm{PO}_{4}$, and $\mathrm{Si}(\mathrm{OH})_{4}$ concentrations were determined on a Technicon Autoanalyzer II using automated methods (Grasshoff 1966, Pavlou 1972). Ciliate and metazoan microzooplankton were enumerated in a Sedgwick-Rafter chamber, with a minimum of 3 replicate $1 \mathrm{ml}$ counts from the 5 to $10 \mathrm{ml}$ concentrates. Heterotrophic dinoflagellates and microflagellates were not enumerated.

Chl a production and grazing by microzooplankton was calculated using the equations of Frost (1972), and treating the $<10 \mu \mathrm{m}$ plankton community as a control lacking grazers of autotrophic cells. Calculations of mean grazing and growth rates were made for both $<10 \mu \mathrm{m}$ and $<5 \mu \mathrm{m} \mathrm{chl} a$ in each experiment. The chl a growth rates represent net increases in the presence of heterotrophs passing a $10 \mu \mathrm{m}$ mesh; grazing rates represent ingestion by 10 to $202 \mu \mathrm{m}$ inicrozooplankton. Growth rates of autotrophic nanoplankton in bags with and without 10 to $202 \mu \mathrm{m}$ microzooplankton are assumed to be identical (see 'Discussion').

Incident irradiance was measured at the Eppley Laboratories in Newport, located $7 \mathrm{~km}$ from the experimental site. Light extinction was determined using a Secchi disk, and the extinction coefficient (k) was calculated as $\mathrm{k}=1.44 / \mathrm{z}$, where $\mathrm{z}(\mathrm{m})$ was the depth of disappearance of the Secchi disk (Holmes 1970). Light measurements inside the bags using a Biospherical Instruments QSL-100 quantum sensor indicated that autoclaved dialysis membranes transmitted $85 \%$ of surface incident irradiance.

Correlations between rate and biomass measurements were analyzed using functional regressions as 
both variables were subject to measurement error (Ricker 1973, Laws \& Archie 1981). All statistical tests were performed according to Snedecor \& Cochran (1967). Significance levels were $p<0.05$ unless otherwise noted.

\section{RESULTS}

Tintinnids were the most abundant ciliate microzooplankton in the dialysis bags (Table 1). Their annual minimum $\left(90 \mathrm{l}^{-1}\right)$ coincided with Olisthodiscus luteus

Table 1. Initial abundance of microzooplankton (no. $\mathrm{l}^{-1}$ ) in the dialysis chambers containing $<202 \mu \mathrm{m}$ plankton

\begin{tabular}{|c|c|c|c|c|c|c|}
\hline Date & Tintinnids & Other Protozoa & Mesodinium & Nauplii & Copepodites & Rotifers \\
\hline 8 Mar 1982 & 3186 & 120 & & 63 & & 27 \\
\hline $15 \mathrm{Mar}$ & 1620 & 33 & & 10 & & 3 \\
\hline $23 \mathrm{Mar}$ & 573 & 60 & & 60 & & 3 \\
\hline $26 \mathrm{Mar}$ & 200 & 217 & & 47 & & 7 \\
\hline $14 \mathrm{Apr}$ & 164 & 70 & & 40 & & \\
\hline $27 \mathrm{Apr}$ & 220 & 177 & & 40 & & \\
\hline $4 \mathrm{May}$ & 330 & 850 & 530 & 100 & & \\
\hline 12 May & 1332 & 1000 & 573 & 93 & & 17 \\
\hline 17 May & 2826 & 433 & 287 & 23 & & 20 \\
\hline 25 May & 2706 & 220 & 233 & 23 & 7 & \\
\hline 2 Jun & 4863 & 1073 & 590 & 127 & 10 & \\
\hline $10 \mathrm{Jun}$ & 7660 & 2753 & 2340 & 57 & 3 & \\
\hline $18 \mathrm{Jun}$ & 694 & 1477 & 3503 & 33 & 3 & 3 \\
\hline $21 \mathrm{Jun}$ & 2111 & 117 & 417 & 30 & & \\
\hline $28 \mathrm{Jun}$ & 176 & 396 & & 44 & 8 & \\
\hline $6 \mathrm{Jul}$ & 123 & 370 & & 27 & 10 & \\
\hline $12 \mathrm{Jul}$ & 90 & 1440 & & 90 & 7 & \\
\hline $21 \mathrm{JuI}$ & 550 & 430 & & 53 & & \\
\hline $1 \mathrm{Aug}$ & 8181 & 1360 & 670 & 40 & 3 & 3 \\
\hline $4 \mathrm{Aug}$ & 4407 & 1647 & 1057 & 183 & & \\
\hline 11 Aug & 1286 & 1254 & 243 & 93 & & \\
\hline $18 \mathrm{Aug}$ & 1144 & 1310 & 450 & 67 & & \\
\hline 27 Aug & 2624 & 1707 & 7100 & 50 & & \\
\hline 1 Sep & 2500 & 1257 & 2537 & 40 & & \\
\hline 5 Sep & 4828 & 2097 & 2530 & 17 & 3 & \\
\hline $15 \mathrm{Sep}$ & 2711 & 2803 & 70 & 43 & 3 & 7 \\
\hline $23 \mathrm{Sep}$ & 1899 & 150 & 27 & 60 & 3 & 43 \\
\hline 2 Oct & 958 & 83 & 130 & 80 & 3 & 7 \\
\hline 15 Oct & 249 & 63 & 73 & 23 & 7 & \\
\hline 19 Oct & 784 & 107 & 23 & 47 & 3 & \\
\hline 28 Oct & 670 & 247 & 50 & 27 & 3 & \\
\hline $1 \mathrm{Nov}$ & 1770 & 10 & & 20 & 3 & \\
\hline $8 \mathrm{Nov}$ & 1131 & 30 & & 17 & 3 & \\
\hline $15 \mathrm{Nov}$ & 803 & 20 & & 20 & 3 & \\
\hline $22 \mathrm{Nov}$ & 476 & 420 & 1050 & 53 & 10 & 6 \\
\hline $30 \mathrm{Nov}$ & 2040 & 120 & 713 & 73 & 10 & \\
\hline $7 \mathrm{Dec}$ & 1270 & 143 & & 60 & 10 & \\
\hline $14 \mathrm{Dec}$ & 222 & 137 & & 50 & 7 & \\
\hline $20 \mathrm{Dec}$ & 626 & 450 & & 77 & 7 & \\
\hline $27 \mathrm{Dec}$ & 491 & 113 & & 93 & 7 & \\
\hline 1 Jan 1983 & 346 & 26 & & & & \\
\hline $9 \mathrm{Jan}$ & 427 & 117 & & 40 & & \\
\hline $17 \mathrm{Jan}$ & 247 & 83 & & 20 & & \\
\hline $25 \mathrm{Jan}$ & 634 & 127 & & 83 & & \\
\hline $30 \mathrm{Jan}$ & 767 & 50 & & 57 & & \\
\hline $14 \mathrm{Feb}$ & 429 & 10 & & 40 & & \\
\hline $22 \mathrm{Feb}$ & 306 & 5 & & 100 & & 6 \\
\hline $27 \mathrm{Feb}$ & 263 & 33 & & 90 & 7 & 3 \\
\hline $8 \mathrm{Mar}$ & 2280 & 140 & & 90 & 3 & 7 \\
\hline $20 \mathrm{Mar}$ & 400 & 23 & & 83 & & 7 \\
\hline $24 \mathrm{Mar}$ & 618 & 163 & & 133 & & 3 \\
\hline $29 \mathrm{Mar}$ & 714 & 8 & & 10 & 4 & \\
\hline
\end{tabular}


blooms in late June and early July; maximum tintinnid abundances were found immediately before $\left(7.6 \times 10^{3}\right.$ $\left.1^{-1}\right)$ and after $\left(8.2 \times 10^{3} 1^{-1}\right)$ these blooms. With the exception of dates with high $O$. luteus concentrations, tintinnids consistently exceeded $10^{3} \mathrm{l}^{-1}$ from May through September; the annual mean abundance was $1.5 \times 10^{3} 1^{-1}\left(\mathrm{SD}=1.8 \times 10^{3}, \mathrm{n}=52\right)$. Nine genera representing 26 species were found; Tintinnopsis was the most important genus in terms of both abundance and species number (Verity 1984). Protozoa other than tintinnids, predominantly holotrich and 'sheathed' (e.g. Laboea) and 'nonsheathed' (e.g. Lohmanniella) oligotrich ciliates, were numerically second in importance with an annual mean of $530 \mathrm{l}^{-1}(\mathrm{SD}=720, \mathrm{n}=$ 52). Their seasonal abundance cycle was similar to that of tintinnids, with highest numbers occurring in May, early June, August, and September, and lowest abundances during mid-summer and winter. The photosynthetic gymnostome ciliate, Mesodinium rubrum, bloomed during May-June and August-September when temperatures ranges from 10 to $23^{\circ} \mathrm{C}$. Maximum abundance was $7.1 \times 10^{3} 1^{-1}$, and the annual mean was $4851^{-1}\left(\mathrm{SD}=1.2 \times 10^{3}, \mathrm{n}=52\right)$. Copepod nauplii, predominantly the genus Acartia, were present year-round, with an annual average of $521^{-1}$ (SD $=35, \mathrm{n}=52$ ). Highest abundances occurred in June, August, and February-March; minima were observed in November and January. Rotifers and copepodite stages of copepods each averaged $31^{-1}$ on an annual basis. Rotifers were generally present during the winter and spring; copepodites occurred during summer and fall. Benthic invertebrate larvae rarely passed the $202 \mu \mathrm{m}$ mesh and were seldom observed in the dialysis bags.

The experiments were initiated at the termination of the winter-spring diatom bloom in March 1982, and chl $a$ in the $<153 \mu \mathrm{m},<10 \mu \mathrm{m}$, and $<5 \mu \mathrm{m}$ size fractions was low until late-May (Fig. 1). Olisthodiscus luteus and several uncharacterized microflagellates were abundant throughout June and July; the majority of these cells passed a $10 \mu \mathrm{m}$ mesh. The annual peak in nanoplankton standing stock occurred on August 1 , when chl $a$ was 8.9 and $6.2 \mu \mathrm{g} 1^{-1}$ in the $<10 \mu \mathrm{m}$ and $<5$ $\mu \mathrm{m}$ fractions, respectively. Chain-forming diatoms were abundant during September and peaked in early October with $<153 \mu \mathrm{m}$ chl a of $14.2 \mu \mathrm{g} \mathrm{l}^{-1}$. An extensive bloom of small Thalassiosira species, primarily $T$. constricta, was present during November and December; most of these cells passed $10 \mu \mathrm{m}$ mesh but were retained on $5 \mu \mathrm{m}$ netting. Chl a levels were low during the remainder of the winter, with the exception of short blooms of $T$. constricta in January and several uncharacterized microflagellates in mid-March. The annual mean chl a concentration in the $<153 \mu \mathrm{m}$ fraction was $3.7 \mu \mathrm{g} \mathrm{l}^{-1}$ (range: 0.5 to 14.2 ); chl a passing 10

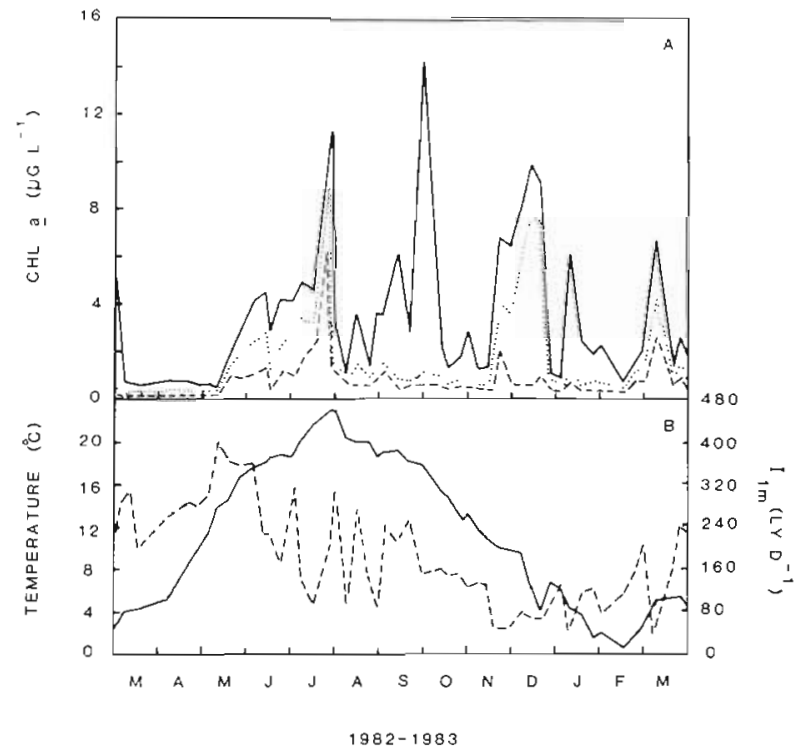

Fig. 1. (A) Chl $a$ in the $<153 \mu \mathrm{m}(-),<10 \mu \mathrm{m}(\cdots)$ ), and $<5 \mu \mathrm{m}$ (- - -) size fractions. (B) Surface water temperature $(-)$ and estimated in situ irradiance at $1 \mathrm{~m} \mathrm{(-} \mathrm{-)} \mathrm{at} \mathrm{the}$ experimental site

$\mu \mathrm{m}$ and $5 \mu \mathrm{m}$ meshes averaged 50 and $24 \%$, respectively.

Chl a growth rates ranged from 0 to $2.2(<10 \mu \mathrm{m})$ and 0 to $2.1(<5 \mu \mathrm{m})$ doublings $\mathrm{d}^{-1}$ (Fig. 2). Growth was highest in the summer, with secondary peaks in late

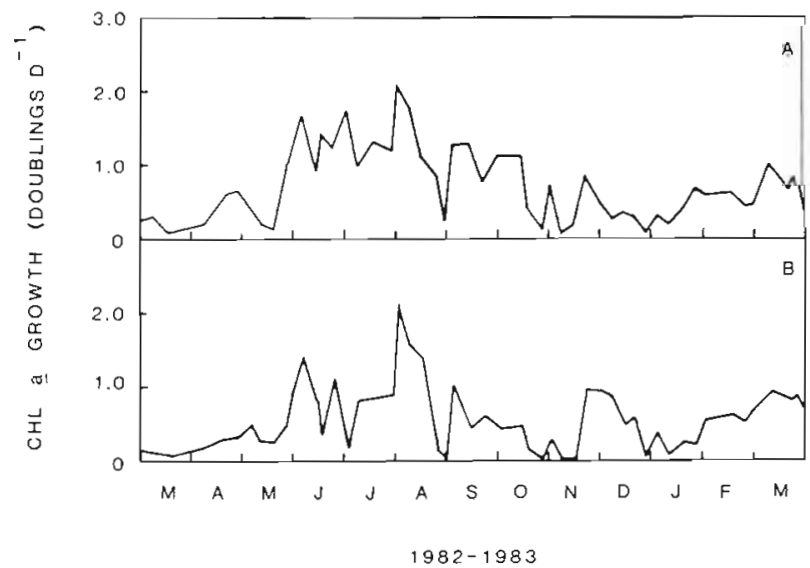

Fig. 2. Seasonal growth rates of chl $a$ in the $(A)<5 \mu m$ and (B) $<10 \mu \mathrm{m}$ size fractions in dialysis bags containing only $<10 \mu \mathrm{m}$ plankton

fall and late winter. Chl $a$ in the $<5 \mu \mathrm{m}$ fraction persistently doubled 1 to 2 times daily from early June to mid-October. Microzooplankton grazing on chl $a$ in the $<10 \mu \mathrm{m}$ fraction exhibited distinct peaks during the late-winter and summer flagellate blooms, and the late-fall Thalassiosira bloom (Fig. 3). The maximum

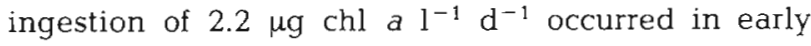




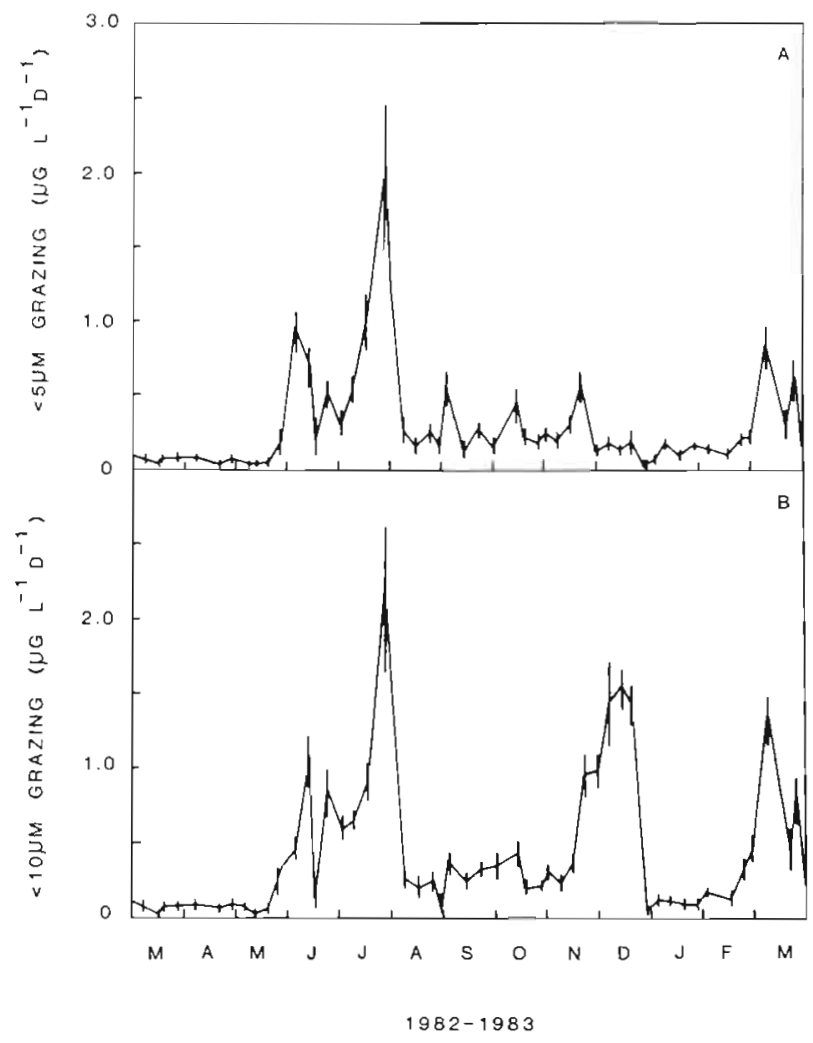

Fig. 3. Seasonal microzooplankton grazing rates on the $(A)<5$ $\mu \mathrm{m}$ and $(B)<10 \mu \mathrm{m}$ size fractions. Error bars represent $\pm 1 \mathrm{SD}$

August $_{i}$ minimal grazing was observed in mid-winter and early spring. Grazing of $<5 \mu \mathrm{m}$ chl a was heaviest during the summer, with removal rates up to $2.1 \mu \mathrm{g} \mathrm{l}^{-1}$ $\mathrm{d}^{-1}$. The fall Thalassiosira bloom was dominated by cells 5 to $10 \mu \mathrm{m}$ in effective size, so that ingestion of $<5$ $\mu \mathrm{m}$ cells was relatively low.

The highest chl a growth rates coincided with elevated temperatures (Fig. 4), although a considerable range in growth rates occurred at a given temperature.

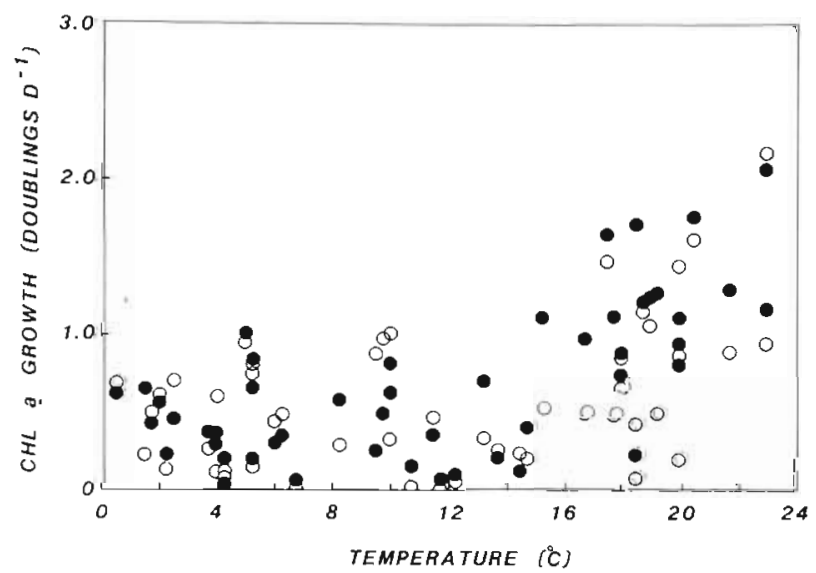

Fig. 4. Growth rates of chl $a$ in the $<10 \mu \mathrm{m}(0)$ and $<5 \mu \mathrm{m}(\bullet)$ size fractions as a function of temperature
An exponential fit of the log-transformed maximum growth rate $\left(\mathrm{K}_{\mathrm{m}}\right)$ at each temperature $(\mathrm{T})$ yielded:

$$
\mathrm{K}_{\mathrm{m}}=0.48 \mathrm{e}^{0.05(\mathrm{~T})}, \mathrm{n}=21, \mathrm{r}^{2}=0.50 \text {. }
$$

The exponent is equivalent to a $Q_{10}$ of 1.7 . Whereas phytoplankton growth was temperature-dependent, microzooplankton grazing rates were not clearly related to temperature (Fig. 5): elevated ingestion

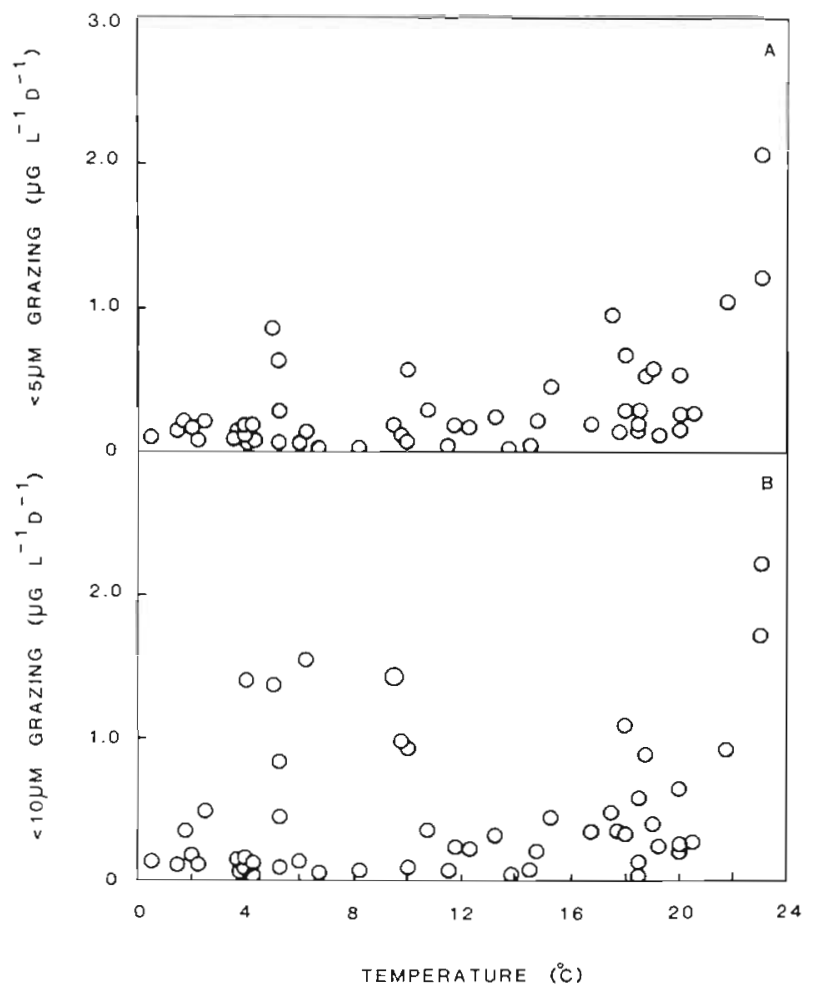

Fig. 5. Microzooplankton grazing rates on the (A) $<5 \mu \mathrm{m}$ and (B) $<10 \mu \mathrm{m}$ size fractions as a function of temperature

occurred during the fall Thalassiosira event $\left(4\right.$ to $\left.10^{\circ} \mathrm{C}\right)$ and the summer flagellate blooms (18 to $\left.24^{\circ} \mathrm{C}\right)$.

Daily chl a production in dialysis bags containing only $<10 \mu \mathrm{m}$ plankton ranged from 0 to $8.2(<10 \mu \mathrm{m}$ cells) and 0 to $7.8\left(<5 \mu \mathrm{m}\right.$ cells) $\mu \mathrm{g} \mathrm{l}^{-1} \mathrm{~d}^{-1}$. The standing stock of chl $a$ in each size class was linearly related to the daily production rate (Fig. 6): high nanoplankton concentrations were observed when production was elevated, and low chl a levels coincided with low production. Microzooplankton grazing on both size fractions exhibited significant $(p<0.05)$ linear relations with the standing stock (Fig. 7) and production rates (Fig. 8) of phototrophic nanoplankton in Narragansett Bay. Increased phytoplankton productivity was associated with enhanced transfer to the microzooplankton community, an effect especially evident in the $<10 \mu \mathrm{m}$ size class. In the $<5 \mu \mathrm{m}$ fraction, a single experiment exhibited very high nanoplankton abun- 


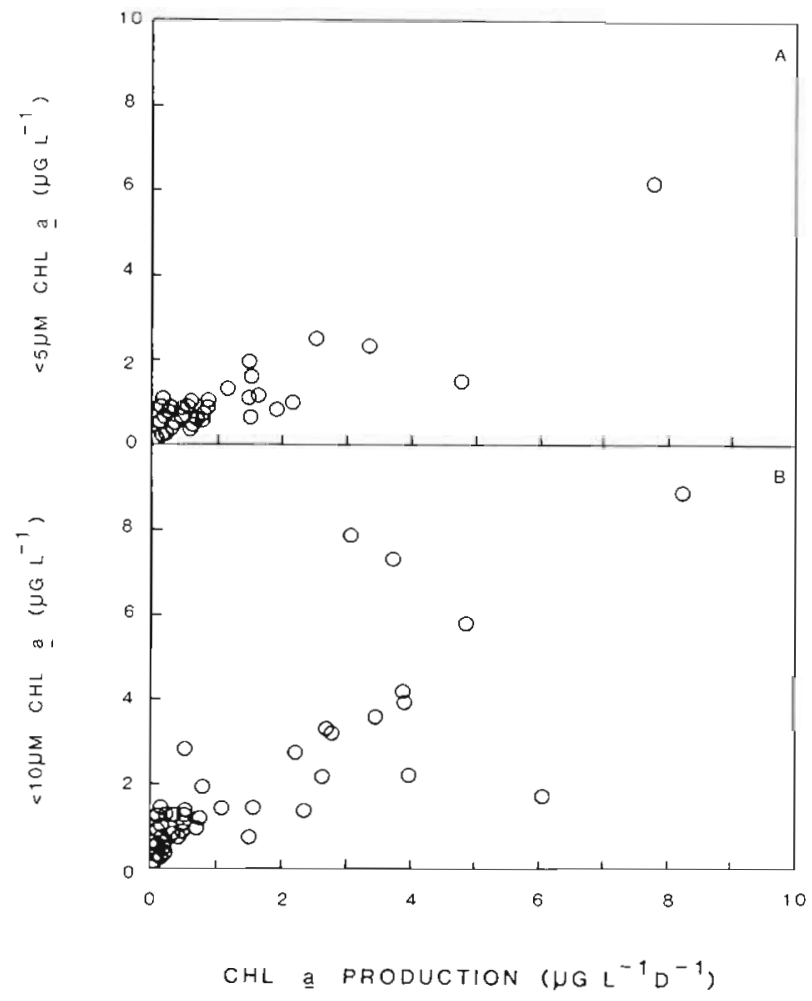

Fig. 6. Chl a concentration in the (A) $<5 \mu \mathrm{m}$ and $(B)<10 \mu \mathrm{m}$ fractions as a function of chl a production. $<5 \mu \mathrm{m} \mathrm{chl} a=0.29$ $+0.68(<5 \mu \mathrm{m}$ chl a production $), \mathrm{r}^{2}=0.77, \mathrm{n}=52, \mathrm{p}<0.05$. $<10 \mu \mathrm{m}$ chl $a=0.32+1.08(<10 \mu \mathrm{m}$ chl a production $), \mathrm{r}^{2}=$ $0.71, \mathrm{n}=52, \mathrm{p}<0.05$

dance, production, and grazing by microzooplankton. Comparison of slopes calculated with and without this experiment indicated no significant differences, nor are the intercepts significantly different from zero in either case.

\section{DISCUSSION}

Grazing rates were measured as differences in chl a concentrations after $24 \mathrm{~h}$ in the presence and absence of 10 to $202 \mu \mathrm{m}$ microzooplankton. Two assumptions are inherent in these calculations. The first is that $<10$ $\mu m$ phytoplankton grew at the same rate in bags containing $<10 \mu \mathrm{m}$ and $<202 \mu \mathrm{m}$ plankton. This would seem a valid assumption because the temperature and light fields were similar for both communities within a given experiment. Nitrogen is the major nutrient limiting phytoplankton growth in lower Narragansett Bay (Smayda 1974). Similar nitrogen concentrations were present in the $<10 \mu \mathrm{m}$ and $<202 \mu \mathrm{m}$ bags, and $\mathrm{NO}_{3}$ or $\mathrm{NH}_{4}$ was always detectable after $24 \mathrm{~h}$ (Fig. 9). In addition, $\mathrm{PO}_{4}$ and $\mathrm{Si}(\mathrm{OH})_{4}$ were present in excess relative to dissolved inorganic nitrogen, and initial and final concentrations were generally similar (Fig. 10).

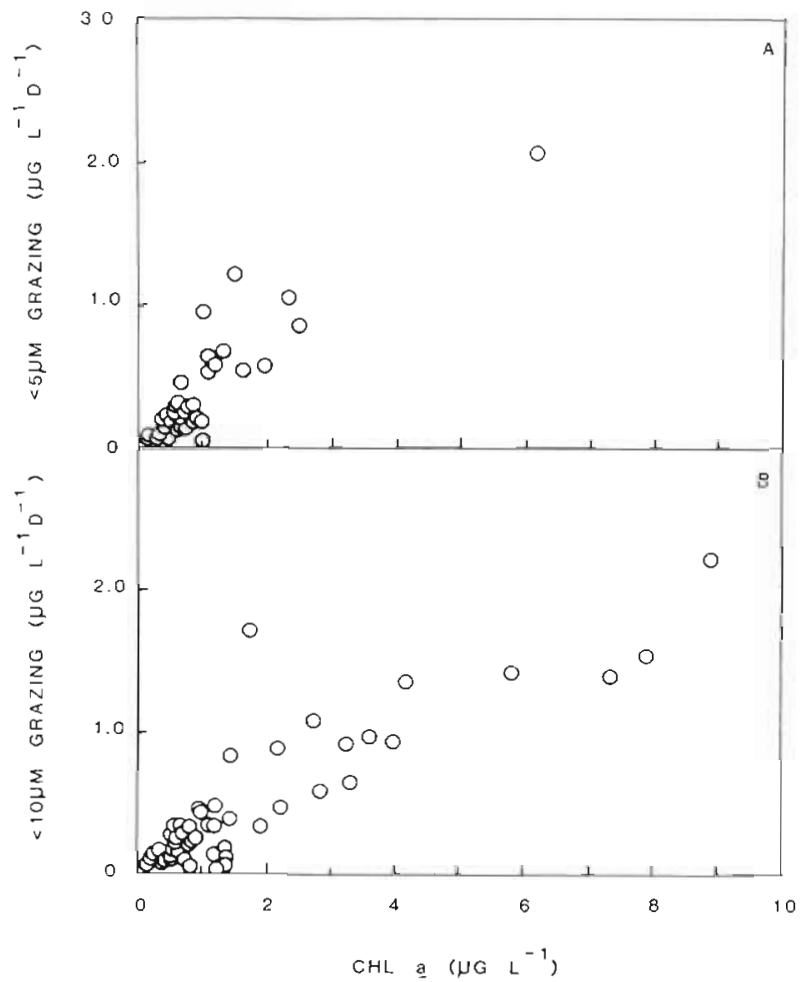

Fig. 7. Microzooplankton grazing rates on the (A) $<5 \mu \mathrm{m}$ and (B) $<10 \mu \mathrm{m}$ size fractions as a function of $\mathrm{chl}$ a concentration in each size class. $<5 \mu \mathrm{m}$ grazing rate $=-0.03+0.41(<5 \mu \mathrm{m}$ chl a), $\mathrm{r}^{2}=0.80, \mathrm{p}<0.01 .<10 \mu \mathrm{m}$ grazing rate $=0.02+0.26$ $(<10 \mu \mathrm{m}$ chl $a), \mathrm{r}^{2}=0.77, \mathrm{p}<0.05$

These data indicate that transport across the dialysis membrane and remineralization within the bags was sufficient to meet uptake requirements during the $24 \mathrm{~h}$ incubations. Thus the assumption of similar photosynthetic nanoplankton growth rates in dialysis bags with and without 10 to $202 \mu \mathrm{m}$ microzooplankton appears justified.

A corollary is that phytoplankton species interactions influencing phototrophic nanoplankton growth were similar in bags with and without microzooplankton. Relevant literature is scarce, with the classic example being the apparent reciprocal co-dominance of Skeletonema costatum and Olisthodiscus luteus in Narragansett Bay. This effect was originally attributed to excretion of low molecular weight $(<2,000)$ inhibitory compounds by O. luteus (Pratt 1966, Stuart 1972); however, more recent analysis suggests that these events may be mediated more by selective grazing than phytoplankton interactions (Tomas 1980). Dialysis membranes permit passage of compounds of higher molecular weight $(<12,000)$, so that in the present study external metabolites derived from phytoplankton cells should have affected all the bags equally.

The second assumption is that significant grazing on 


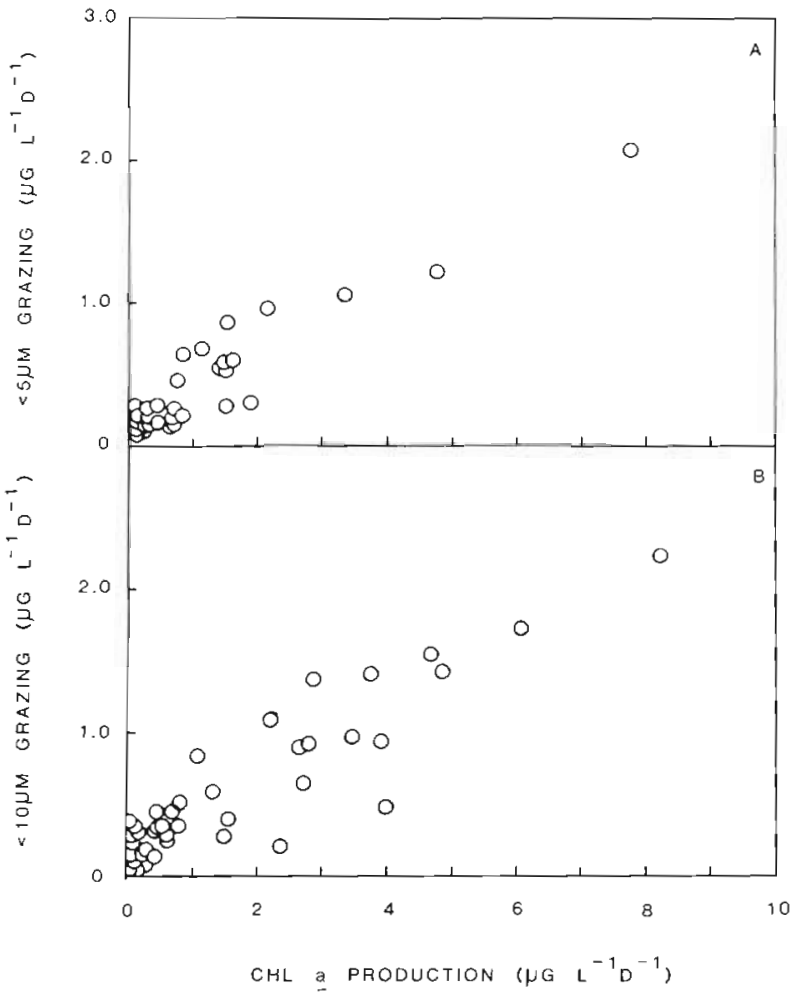

Fig. 8. Microzooplankton grazing rates on the (A) $<5 \mu \mathrm{m}$ and (B) $<10 \mu \mathrm{m}$ size fractions as a function of chl a production rates in that size class. $<5 \mu \mathrm{m}$ grazing rate $=0.09+0.28 \ell<5$ $\mu \mathrm{m}$ chl a production), $\mathrm{r}^{2}=0.89, \mathrm{p}<0.01,<10 \mu \mathrm{m}$ grazing rate $=0.10+0.28(<10 \mu \mathrm{m} c h l$ a production $), \mathrm{r}^{2}=0.85, \mathrm{p}<0.01$ autotrophic phytoplankton did not occur in the control $(<10 \mu \mathrm{m})$ bags. Regular inspection of the $<10 \mu \mathrm{m}$ plankton communities indicated that few ciliates passed a $10 \mu \mathrm{m}$ mesh and rarely increased in abundance, in agreement with similar observations of summer nanoplankton populations in Narragansett Bay (Furnas 1982). The impact of $<10 \mu \mathrm{m}$ heterotrophic microflagellates and dinoflagellates on photosynthetic nanoplankton is unknown. The latter may be significant grazers in tropical oceanic waters (Lessard \& Swift 1985), but most coastal forms exceed $10 \mu \mathrm{m}$ in effective size. Heterotrophic microflagellates are considered to be primarily bacterivorous (Fenchel 1982), although at least one species fed equally well on bacteria and selected phytoplankton (Goldman \& Caron 1985). Zooflageliates are a potential food source for ciliates (Sieburth \& Davis 1982), and the seasonal cycle and abundance of apochlorotic flagellates in Narragansett Bay is similar to that of photosynthetic nanoplankton (Davis et al. 1985). Although Narragansett Bay tintinnids did not survive in culture on a diet of heterotrophic microflagellates (Verity unpubl.), to the extent that herbivory by heterotrophic nanoplankton and predation on these heterotrophs by 10 to $202 \mu \mathrm{m}$ microzooplankton was important, both the photosynthetic nanoplankton growth and microzooplankton grazing rates were conservative estimates.

Tintinnids were the most abundant ciliate microzooplankton at the experimental site in lower Narragansett Bay. The seasonal pattern of maximal abundances
Fig. 9. (A) $\mathrm{NO}_{3}$ and (B) $\mathrm{NH}_{4}$ concentrations at the initiation of each experiment $(\Delta)$ and after $24 \mathrm{~h}$ in the $<202 \mu \mathrm{m}(0)$ and $<10 \mu \mathrm{m}$ ( $\bullet$ ) dialysis bags

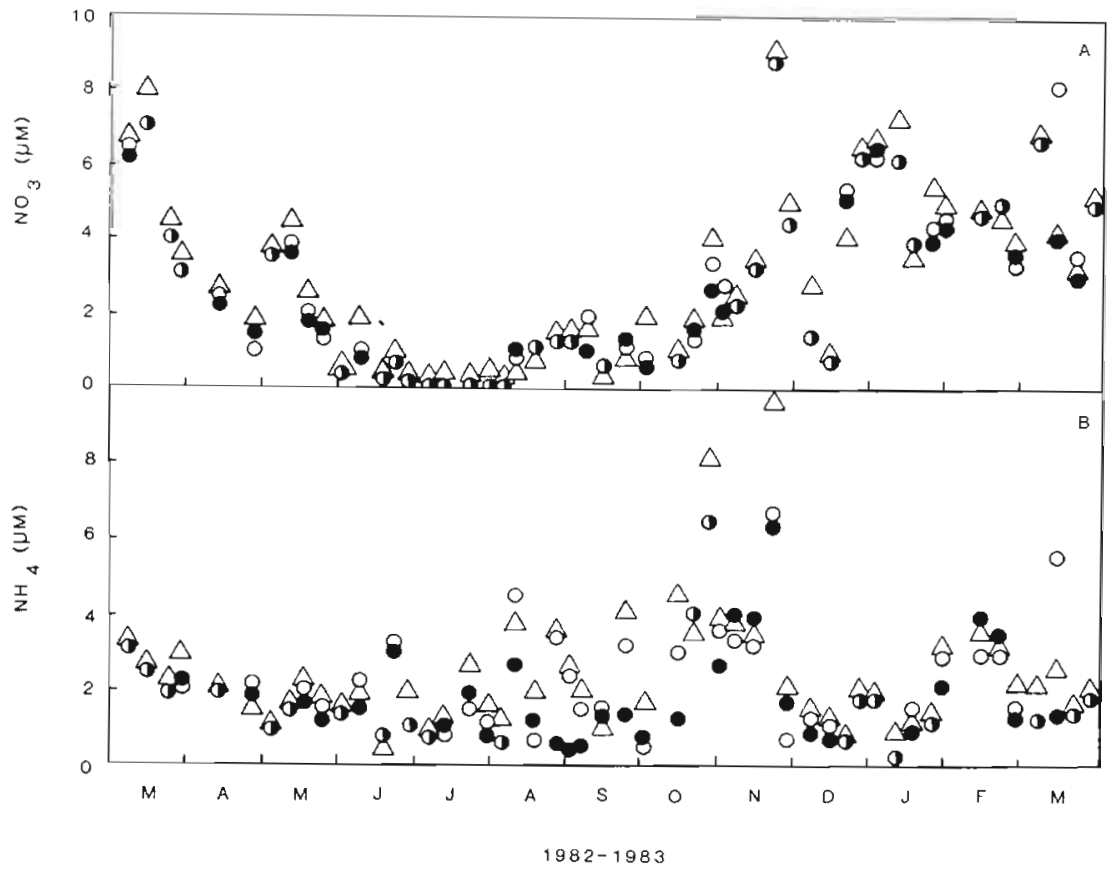




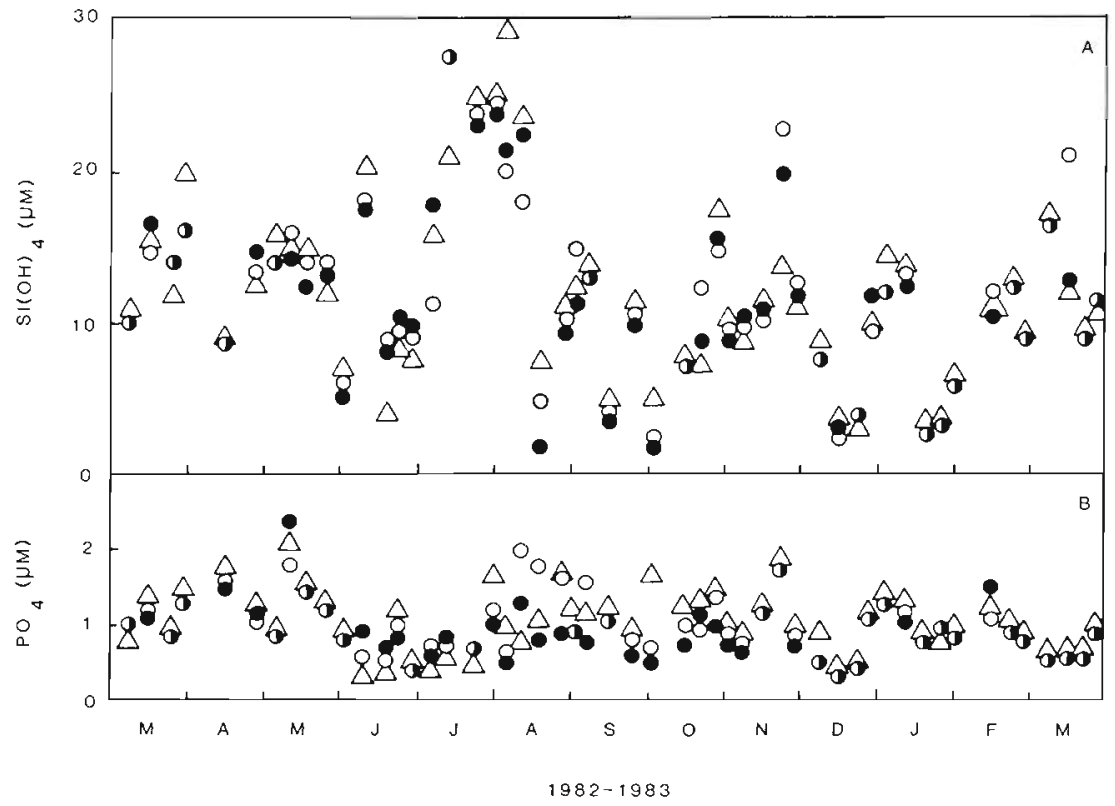

Fig. 10. (A) $\mathrm{Si}(\mathrm{OH})_{4}$ and (B) $\mathrm{PO}_{4}$ concentrations in the dialysis bags. Symbols as in Fig. 9 in spring and late-summer, separated by mid-summer and winter minima, is similar to previous findings in Narragansett Bay (Hargraves 1981, Verity 1984). The summer decline is due to the toxicity of the flagellate Olisthodiscus luteus to tintinnids (Verity \& Stoecker 1982). The winter minimum reflects reduced food availability and growth rates at low temperatures (Verity 1985, 1986). Tintinnid abundance was not significantly different $(p<0.05$ ) from the 3 yr mean for another site in lower Narragansett Bay, and was comparable to that observed in other shallow coastal waters (see summary in Verity 1984).

Protozoa other than tintinnids, predominantly oligotrich and holotrich ciliates, were second in numerical importance, consistent with observations in other shallow temperate waters (Capriulo \& Carpenter 1980, Burkhill 1982). Occasional comparisons of counts on living and preserved material from Narragansett Bay indicated good agreement, as low levels of detritus did not obscure settled ciliates (Dale \& Burkhill 1982). Non-loricate ciliates are generally more abundant than tintinnids in offshore waters (Beers \& Stewart 1970, Johansen 1976). Mesodinium rubrum, a gymnostome ciliate containing photosynthetic symbionts (Taylor et al. 1971), bloomed in spring and late-summer in Narragansett Bay over a temperature range of 10 to $23^{\circ} \mathrm{C}$. The oral cone of this ciliate is reduced and the mouth is vestigial, lacking oral tentacles; $M$. rubrum is considered a functional autotroph (Smith \& Barber 1979). These ciliates did not pass a $10 \mu \mathrm{m}$ mesh, so that nanoplankton chl a growth rates in $<10 \mu \mathrm{m}$ dialysis bags are independent of $M$. rubrum population dynamics.
Copepod nauplii, primarily Acartia NI-IV, were the most abundant metazoan microzooplankton. They were characterized by highest abundances in the spring (A. hudsonica) and late summer (A. tonsa), in agreement with previous investigations (Durbin \& Durbin 1981). The general absence of older nauplii reflects their reduced abundance and body lengths sufficient for some to be excluded by the $202 \mu \mathrm{m}$ mesh. Copepodite stages were found in low numbers, and other microzooplankton occurred infrequently.

Grazing rates on the $<10 \mu \mathrm{m}$ and $<5 \mu \mathrm{m}$ chl a size fractions were highest during mid-summer and latewinter microflagellate blooms. Microzooplankton then ingested nanoplankton at rates in excess of $1 \mu \mathrm{g}$ chl a $\mathrm{l}^{-1} \mathrm{~d}^{-1}$. In addition, many of these herbivores potentially fed on phototrophic cells $>10 \mu \mathrm{m}$ in effective size, so that the present removal rates provide only a conservative estimate of their total grazing impact. Tintinnids were the most abundant ciliate microzooplankton during the coincident periods of high grazing rates and microflagellate blooms. Grazing on the $<10$ $\mu \mathrm{m}$ fraction was also elevated during a $5 \mathrm{wk}$ bloom of small Thalassiosira species in November and December. Most of these diatoms passed a $10 \mu \mathrm{m}$ mesh but were retained by $5 \mu \mathrm{m}$ netting, as found by Furnas (1982). Tintinnids were not abundant during this period, and laboratory experiments indicated that Thalassiosira is an unsuitable food for coastal species (Verity \& Villareal 1985). The most important grazers at this time were probably copepod nauplii and copepodites.

Grazing by microzooplankton was proposed as a mechanism regulating nanoplankton populations in 
Canadian waters (Blackbourn 1974, Johansen 1976), but estimates of their grazing impact are indirect and range from $<10$ to $100 \%$ of net primary production. The only annual estimates suggest consumption of $60 \%$ of total phytoplankton production in the Solent estuary (Burkhill 1982) and $27 \%$ of production in Long Island Sound (Capriulo \& Carpenter 1983). In Narragansett Bay, the slope of the functional regression of grazing rate on chl a production indicated that $28 \%$ of $<10 \mu \mathrm{m}$ and $<5 \mu \mathrm{m}$ chl a production was consumed by microzooplankton. However, when grazing impact is calculated for each experiment and summed for all, an annual mean grazing impact of $62 \%$ of production in both size fractions is obtained. The discrepancy reflects the fact that grazing by microzooplankton equalled or exceeded nanoplankton growth at low temperatures (Fig. 11) and low production rates (Fig. 12). Below $4{ }^{\circ} \mathrm{C}$, the grazing impact invariably exceeded $60 \%$ of nanoplankton production. Below $15^{\circ} \mathrm{C}$, microzooplankton ingested a minimum of $25 \%$

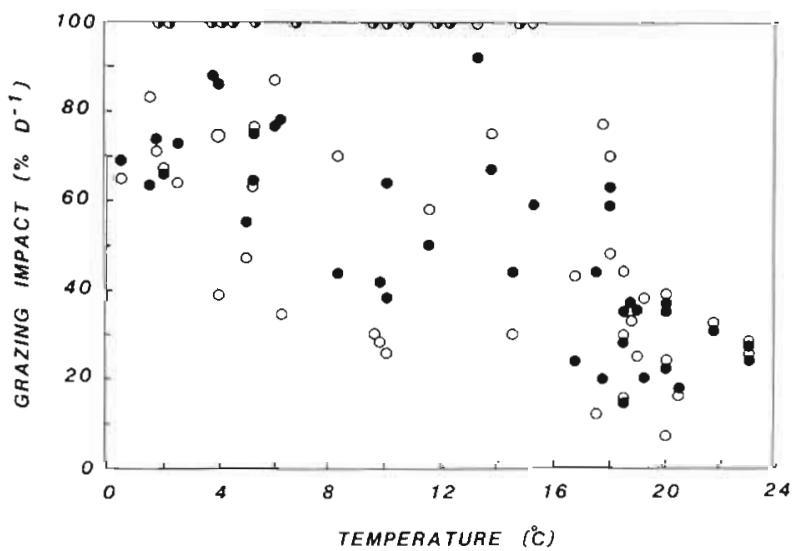

Fig. 11. Microzooplankton grazing impact ( $\% \mathrm{chl}$ a production per day) on the $<10 \mu \mathrm{m}(O)$ and $<5 \mu \mathrm{m}(\bullet)$ size fractions as a function of temperature

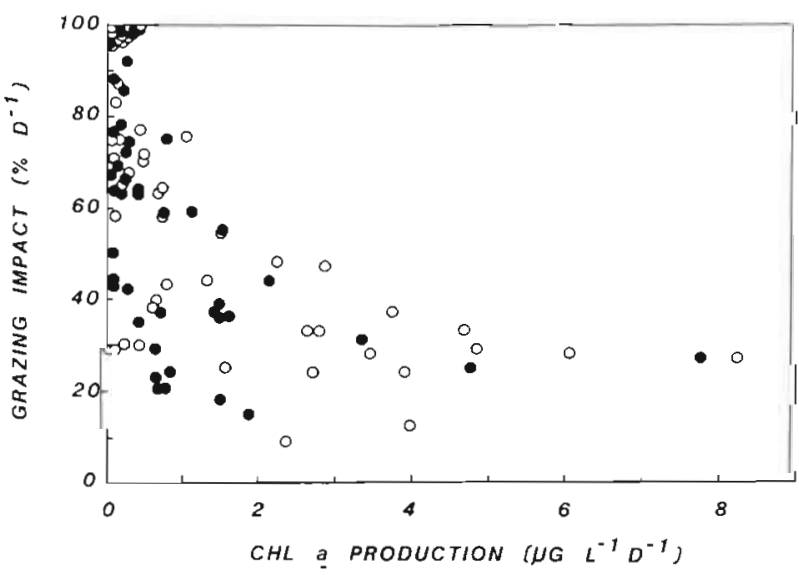

Fig. 12. Microzooplankton grazing impact as a function of chl a production in each size fraction. Symbols as in Fig. 11 of daily production, and, in 13 of the 34 experiments, all of the chl a production was ingested. Production was $<0.5 \mu \mathrm{g} \mathrm{l}^{-1} \mathrm{~d}^{-1}$ in every experiment in which grazing equalled or exceeded production. Above $15^{\circ} \mathrm{C}$, grazing did not match phytoplankton growth. The net result was that the standing stock of chl $a$ in the $<10 \mu \mathrm{m}$ and $<5 \mu m$ fractions exhibited significant $(p$ $<0.05$ ) linear relations with the difference between production and grazing (Fig. 13). For much of the year,

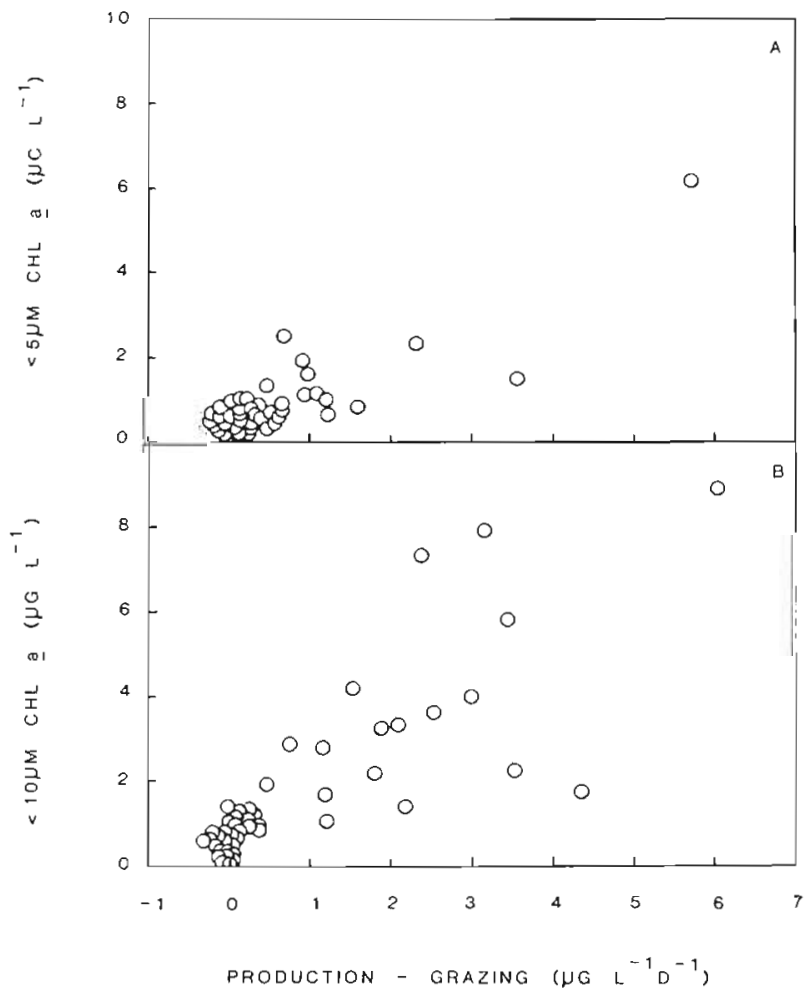

Fig. 13. Chl a standing stock in the $(\mathrm{A})<5 \mu \mathrm{m}$ and $(\mathrm{B})<10 \mu \mathrm{m}$ size fractions as a function of the difference between chl a production (P) and grazing (G) rates in each size class. $<5 \mu \mathrm{m}$ chl $a=0.38+0.92(<5 \mu \mathrm{m} P-G), \mathrm{r}^{2}=0.72, \mathrm{p}<0.01 .<10 \mu \mathrm{m}$

chl $a=0.49+1.44(<10 \mu \mathrm{mP}-\mathrm{G}), \mathrm{r}^{2}=0.66, \mathrm{p}<0.01$

microzooplankton grazing kept pace with temperature-limited phytoplankton growth, and nanoplankton community biomass remained low. Nanoplankton growth rates increased with temperature during the spring and summer, and microzooplankton grazing accounted for a smaller fraction of production; high nanoplankton standing stocks were found at this time. Thus, microzooplankton grazing contributed to seasonal variations in the size structure of phytoplankton communities in Narragansett Bay. High grazing impact on nanoplankton during the cold months coincided with netplankton $(>10 \mu \mathrm{m})$ dominance of phytoplankton community biomass; low grazing impact during the summer was associated with nanoplankton 
dominance. The low microzooplankton grazing impact at higher temperatures, coupled with rapid reductions of copepod filtering efficiency on $<10 \mu \mathrm{m}$ particles (Nival \& Nival 1976), suggest that zooplankton grazing alone cannot regulate nanoplankton populations during the summer in Narragansett Bay. Additional factors such as benthic grazing (Officer et al. 1982) may be important at this time.

Acknowledgements. I thank C. Griswold and T. Villareal for sampling assistance, and D. French and T. Villareal for sharing hours on the Autoanalyzer. N. Hairston, Jr., P. E. Hargraves, S. Levings, J. McN. Sieburth, T. J. Smayda, D. Stoecker, and 2 anonymous reviewers made valuable comments on various drafts. This work was supported by the Department of Commerce (NOAA) Grant No. NA80RA-00064 awarded to T. J. Smayda.

\section{LITERATURE CITED}

Beers, J. R., Stewart, G. L. (1970). The ecology of the plankton off La Jolla, California, in the period April through September 1967. VI. Numerical abundance and estimated biomass of microzooplankton. Bull. Scripps Inst. Ocenogr. 17: $67-87$

Blackbourn, D. J. (1974). The feeding biology of tintinnid Protozoa and some other inshore microzooplankton. Ph. D. thesis, Univ. British Columbia, Vancouver

Burkhill, P. H. (1982). Ciliates and other microplankton components of a nearshore food web: standing stocks and production processes. Ann. Inst. océanogr. Paris 58 (S): 335-349

Capriulo, G. M., Carpenter, E. J. (1980). Grazing by 35 to 202 $\mu \mathrm{m}$ microzooplankton in Long Island Sound. Mar. Biol. 56: 319-326

Capriulo, G. M., Carpenter, E. J. (1983). Abundance, species composition, and feeding impact of tintinnid micro-zooplankton in central Long Island Sound. Mar. Ecol. Prog. Ser. 10: 277-288

Dale, T., Burkhill, P. H. (1982). Live counting - a quick and simple technique for enumerating pelagic ciliates. Ann. Inst. océanogr. Paris 58 (S) : 267-276

Davis, P. G., Caron, D. A., Johnson, P. W., Sieburth, J. McN. (1985). Phototrophic and apochlorotic components of picoplankton and nanoplankton in the North Atlantic: geographic, vertical, seasonal, and diel distributions. Mar. Ecol. Prog. Ser. 21: 15-26

Durbin, A. G., Durbin, E. G. (1981). Standing stock and estimated production rates of phytoplankton and zooplankton in Narragansett Bay, Rhode Island. Estuaries 4: $24-41$

Eppley, R. W. (1980). Estimating phytoplankton growth rates in the central oligotrophic oceans. In: Falkowski, P. G. (ed.) Primary productivity in the sea. Plenum Press, New York, p. 231-242

Fenchel, T. (1982). Ecology of heterotrophic microflagellates. IV. Quantitative occurrence and importance as bacterial consumers. Mar. Ecol. Prog. Ser. 9: 35-42

Frost, B. W. (1972). Effects of size and concentration of food particles on the feeding behavior of the marine planktonic copepod Calanus pacificus. Limnol. Oceanogr. 17: 805-819
Furnas, M. J. (1982). Growth rates of summer nanoplankton $(<10 \mu \mathrm{m})$ populations in lower Narragansett Bay, Rhode Island, USA. Mar. Biol. 70: 105-115

Goldman, J. C., Caron, D. A. (1985). Experimental studies on an omnivorous microflagellate: implications for grazing and nutrient regeneration in the marine microbial food chain. Deep Sea Res. 32: 899-915

Grasshoff, K. (1966). Automatic determination of fluoride, phosphate, and silicate in seawater. In: Skiggs, L. T. (ed.) Automation in analytic chemistry. 1965 Technicon Symposium, Mediad, New York, p. 304-307

Hama, T. Miyazaki, T., Ogawa, Y., Iwakumi, T., Takahashi, M., Otsuki, A., Ichimura, S. (1983). Measurement of photosynthetic production of a marine phytoplankton population using a stable ${ }^{13} \mathrm{C}$ isotope. Mar. Biol. 73: 31-36

Hargraves, P. E. (1981). Seasonal variations in tintinnids (Ciliophora: Oligotrichida) in Narragansett Bay, Rhode Island, USA. J. Plankton Res. 3: 81-91

Heinbokel, J. F. (1978). Studies on the functional role of tintinnids in the Southem California Bight. I. Grazing and growth rates in laboratory cultures. Mar. Biol, 47: 177-189

Heinbokel, J. F., Beers, J. R. (1979). Studies on the functional role of tintinnids in the Southern California Bight. III. Grazing impact of natural assemblages. Mar. Biol. 52: 23-32

Holmes, R. W. (1970). The Secchi disk in turbid coastal waters. Limnol. Oceanogr. 15: 688-694

Holm-Hansen, O., Lorenzen, C. J., Holmes, R. W., Strickland, J. D. H. (1965). Fluorometric determination of chlorophyll. J. Cons. 25: 115-128

Jenkins, W. J. (1982). Oxygen utilization rates in North Atlantic subtropical gyre and primary production in oligotrophic systems. Nature, Lond. 300: 246-248

Johansen, P. L. (1976). A study of tintinnids and other Protozoa in eastern Canadian waters, with special reference to tintinnid feeding, nitrogen excretion, and reproduction rates. $\mathrm{Ph}$. D. thesis, Dalhousie Univ., Halifax

Karl, D. M., Winn, C. D., Wong, D. C. L. (1981). RNA synthesis as a measure of microbial growth in aquatic environments II. Field applications. Mar. Biol. 64: 13-21

Landry, M. R., Hassett, R. P. (1982). Estimating the grazing impact of marine microzooplankton. Mar. Biol. 67: 283-288

Laws, E. A., Archie, J. W. (1981). Appropriate use of regression analyses in marine biology. Mar. Biol. 65: 13-16

Lessard, E. J., Swift, E. (1985). Species-specific grazing rates of heterotrophic dinoflagellates in oceanic waters, measured with a dual-label isotope technique. Mar. Biol. 87 : 289-296

Nival, P., Nival, S. (1976). Particle retention efficiencies of an herbivorous copepod, Acartia clausi: effects on grazing. Limnol. Oceanogr. 21: 24-38

Officer, C. B., Smayda, T. J., Mann, R. (1982). Benthic filterfeeding: a natural eutrophication control. Mar. Ecol. Prog. Ser. 9: 203-210

Pavlou, S. (1972). Phytoplankton growth dynamics. Technical Series I. Chemostat methodology and chemical analyses. Dept. Oceanogr., Univ. Wash. Spec. Rep. No. 52, 1-130

Porter, K. D., Pace, M. L., Battey, J. F. (1979). Ciliate protozoans as links in freshwater food chains. Nature, Lond. 277: $563-565$

Pratt, D. M. (1966). Competition between Skeletonema costatum and Olisthodiscus luteus in Narragansett Bay and in culture. Limnol. Oceanogr. 11:447-455

Redalje, D. G. (1983). Phytoplankton carbon biomass and specific growth rates determined with the labelled chlorophyll a technique. Mar. Ecol. Prog. Ser. 11: 217-225 
Ricker, W. E. (1973). Linear regressions in fishery research. J. Fish. Res. Bd Can. 30: 409-434

Roman, M. R., Rublee, P. A. (1981). A method to determine in situ zooplankton grazing rates on natural particle assemblages. Mar. Biol. 65: 303-309

Sakshaug, E., Jensen, A. (1978). The use of cage cultures in studies of the biochemistry and ecology of marine phytoplankton. Oceanogr. mar. Biol. A. Rev. 16: 81-106

Sheldon, R. W., Sutcliffe, W. H. (1978). Generation time of 3 h for Sargasso Sea microplankton determined by ATP analysis. Limnol. Oceanogr. 23: 1051-1055

Sieburth, J. McN., Davis, P. G. (1982). The role of heterotrophic nanoplankton in the grazing and nurturing of planktonic bacteria in the Sargasso and Caribbean Sea. Ann. Inst. océanogr. Paris 58 (S) : 285-296

Smayda, T. J. (1974). Bioassay of the growth potential of the surface water of lower Narragansett Bay over an annual cycle using the diatom Thalassiosira pseudonana (oceanic clone 13-1). Limnol. Oceanogr. 19: 889-901

Smith, W. O., Jr., Barber, R. T. (1979). A carbon budget for the autotrophic ciliate Mesodinium rubrum. J. Phycol. 15: $27-33$

Snedecor, G. W., Cochran, W. G. (1967). Statistical methods, Iowa State Univ. Press, Ames

Steemann Nielsen, E. (1952). The use of radioactive carbon $\left({ }^{14} \mathrm{C}\right)$ for measuring organic production in the sea. J. Cons. perm. int. Explor. Mer 18: 117-140

Stuart, M. (1972). The effects of Olisthodiscus luteus Carter on the growth of Skeletonema costatum (Grev.) Cleve. M. S. thesis, Univ. Rhode Island, Kingston

Taylor, F. J. R., Blackbourn, D. J., Blackbourn, J. (1971). The red water ciliate Mesodinium rubrum and its incomplete symbionts: a review including new ultrastructural observations. J. Fish. Res. Bd Can. 28: 391-407

Thompson, J. M., Ferguson, A. J. D., Reynolds, C. S. (1982) Natural filtration rates of zooplankton in a closed system: the derivation of a community grazing index. J. Plankton Res. 4: 545-560

Tomas, C. R. (1980). Olisthodiscus luteus (Chrysophyceae). V. Its occurrence, abundance and dynamics in Narragansett Bay, Rhode Island. J. Phycol. 16: 157-166

Venrick, E. L., Beers, J. R., Heinbokel, J. F. (1977). Possible consequences of containing microplankton for physiological rate measurements. J. exp. mar. Biol. Ecol. 26: 55-76

Verity, P. G. (1984). The physiology and ecology of tintinnids in Narragansett Bay, Rhode Island. Ph. D. thesis., Univ. Rhode Island, Kingston

Verity, P. G. (1985). Grazing, respiration, excretion, and growth rates of tintinnids. Limnol. Oceanogr. 30. 1268-1282

Verity, P. G. (1986). Growth rates of natural tintinnid populations in Narragansett Bay. Mar, Ecol. Prog. Ser. 29: $117-126$

Verity, P. G., Stoecker, D. (1982). Effects of Olisthodiscus luteus on the growth and abundance of tintinnids. Mar. Biol. 72: 79-87

Verity, P. G., Villareal, T. A. (1985). The relative food value of diatoms, dinoflagellates, flagellates, and cyanobacteria for tintinnid ciliates. Arch. Protistenk. (in press)

Williams, P. J. LeB., Heinemann, K. R., Marra, J., Purdie, D. A (1983). Comparison of ${ }^{14} \mathrm{C}$ and $\mathrm{O}_{2}$ measurements of phytoplankton production in oligotrophic waters. Nature, Lond. 305: 49-50

This paper was submitted to the editor; it was accepted for printing on December 17, 1985 
